\title{
Legal and Moral Relations: Legal Protection for Women as Victims of Sexual Harassment in the Digital Age
}

\author{
Marisa Kurnianingsih ${ }^{1}$, Kelik Wardiono ${ }^{2}$, Khudzaifah Dimyati ${ }^{3}$, M. Zaki Attirmidzi ${ }^{4}$ \\ \{mk122@ums.ac.id ${ }^{1}$, kw268@ums.ac.id², kd255@ums.ac.id ${ }^{3}$, zakiattirmidzi@gmail.com $\left.{ }^{4}\right\}$ \\ Universitas Muhammadiyah Surakarta, Indonesia ${ }^{1,2,3,4}$
}

\begin{abstract}
Sexual harassment is a term used to designate certain behaviors in society towards women. Sexual harassment has been around for a long time, and is one of the major crimes that have an impact on and have an impact on the social fabric of the Indonesian nation. However, in its development, sexual harassment in the digital world often occurs and even collides with the absence of laws that regulate it, so that women do not get proper protection. This paper is based on a doctrinal (normative) approach which aims to describe the characteristics of sexual harassment in the digital world and describe how legal and moral relations provide legal protection for women victims of sexual harassment. In this paper, it will be noted that the separation of law and morals does not provide protection for women from sexual harassment in the digital world.
\end{abstract}

Keywords: Legal, Moral, Women, Sexual Harassment, Digital

\section{Introduction}

Sexual harassment is a term used to refer to a certain behavior in society towards women, the term sexual harassment is the equivalent of what is in English called "sexual harassment". Therefore, the word harass or harassment always connotes sexual behavior which is considered negative and violates the standard [1]. The United Nations defines sexual harassment as gender based abuse which means:.... Any act of gender based violence that result, in physical sexual, or psycological harm or suffering to women including threats of such acts, coercion, or arbitraty deprivation of liberty, whether occuring in public private live.

Sexual harassment has been around for a long time, and is one of the major crimes that have an impact and take effect on the social fabric of the Indonesian nation [2]. Perpetrators of sexual harassment are not dominated by those who come from the middle or low economic class, let alone less or not at all educated, but have penetrated the social strata from the lowest to the highest strata [3]. Today, with the development of technology, sexual harassment does not only exist in the offline world but has entered the online world. This harassment is harassment of a person's body, sexuality and gender identity facilitated by digital technology. The latest data shows that online-based gender harassment is estimated to increase by more than $40 \%$ in 2020 . There were 281 cases recorded throughout 2019, while there have been 659 cases in the last 10 months alone. This action took the form of distributing photos, videos and screenshots of the conversation between the perpetrator and the victim. The distributed content contains elements of intimacy and victim pornography [4]. 
Moreover, the Covid-19 pandemic, which has forced many people to live in cyberspace to prevent transmission of the virus, has exposed women to an increasingly high level of sexual harassment in the digital world. Ellen Kusuma from Digital At-Risk, revealed that messaging applications such as WhatsApp, Line, Telegram and others are the most frequently used channels for perpetrators to commit sexual harassment $(40 \%)$, followed by social media applications (19\%), video conferencing applications. (16\%), internal company applications (10\%), email (7\%), telephone (5\%), and SMS (3\%) [5]. They need for legal protection for victims of sexual harassment is a must in a rule of law as a guarantee of protection and discrimination against women.

Indonesia is a constitutional state based on the one and only God, so this conception emphasizes that the laws and regulations in Indonesia must always be in line and in no way contradict the basis of one God and religious values and living law that are in accordance with the development of society. In this case, it strengthens its identity and identity as a godly constitution [6]. Seeing that there are cases of sexual harassment against women, the legal umbrella still has weaknesses [7] one of which is the scope of sexual harassment in the Criminal Code. In short, it can be said that the crime of decency is a crime related to morality. This short and simple definition, when studied further to find out how far the scope is, is not easy, because the understanding and boundaries of morals and laws are quite broad and can vary according to the views and values prevailing in society. Moreover, basically every criminal act (offense) contains violations of certain moral values; it can even be said that the law itself is essentially a minimum of moral values (das Recht ist das ethische Minimum). Thus, actually it is not easy to determine the boundaries or scope of decency crimes [3]. For example, the case of a motorcyclist who squeezes a woman's butt while walking and a motorcyclist masturbates under a pedestrian bridge, Ahmad Yani, West Bekasi, where this has been happening for years [8] and an example of a case of a woman being invited to spend the night in a hotel with a man who is not her mahrom, but the woman refuses.

There are no different from the real world, cases of harassment also occur in the digital world, such as via chatting between a man and a woman where a man uses sex-related words to the woman (the victim) either to have sex with him, or praising the victim's body with porn words. As a result, there is an unclear article regarding the criminal act of decency (sexual harassment) that is carried out online which is contained in the Electronics Information and Transaction Law because it does not provide an explanation of what is meant by violating decency [9]. Van Bemmelen gave a description of "destroying morality", namely: a violation of the honor of decency in public is a translation of "public outrage a la pudeur" in Article 303 of the Penal Code, this can be interpreted as "no sexual decency". So polite is an action or behavior that a person does not need to be ashamed of when other people see it or get to know it and also therefore that person generally will not be surprised when he sees or even finds out.

From the introduction above, the issues raised are: 1) What are the characteristics of sexual harassment committed against women in the digital era, seen from the perspective of legal and moral relations? 2) What is the concept of legal protection for women as victims of sexual harassment in the Digital Age, from the perspective of legal and moral relations?

\section{Research Methods}

This research is based on a doctrinal (normative) approach, because it is intended to describe the characteristics of sexual harassment committed against women and explores the 
concept of legal protection for women as victims of sexual harassment in the digital age, seen from the perspective of legal and moral relations. The data needed in this research is secondary data from the internet (online media), collected through library research. The data that has been processed are analyzed by using deductive thinking logic analysis.

\section{Result and Discussion}

\subsection{What Are the Characteristics of Sexual Harassment Committed Against Women in the Digital the Perspective of Legal and Moral Relations?}

Sexual harrasement occurs when the perpetrator makes undesireable sexual advances or seduction, the perpetrator asks the victim to have sexual intercourse or simply asks the victim to send a photo of the victim naked via social media. The terms of sexual harassment include types of cyber harassment, stalking, abuse of images/videos and hate speech that are sexist. In general, several countries in the world divide sexual offenses into two forms, namely nonphysical contact and physical contact. Non-physical contact includes displaying sexual objects directly, luring victims online for sexual purposes, inviting victims to touch sexual organs online and/or offline, peeking, pornography, asking or commenting on sexual matters, suggesting or forcing the victim to masturbate, or witnessing other people masturbating, showing off or exhibiting sexual activities/activities, showing the victim's genitals. While physical contact is in the form of touching or fondling the victim's genitals and/or chest, suggesting or forcing the victim to touch or fondle another person's genitals, oral sex, penetration of the penis into the victim's vagina or anus, penetration of fingers or other objects into the victim's vagina or anus [10].

However, with the development of technology, sexual harassment crimes have developed and shifted forms, crimes that are not only in the real world related to the victim's physical, but also began to penetrate into sexual harassment that attacks the victim psychologically. This is inseparable from the role of social media which takes over life in society which makes human interaction seamless and freer in expressing itself. Freedom in social media makes people start to act more courageously and abandon moral values even then the behavior is considered normal.

The development of the world of digitization has led to many Cyber Crime crimes, one of which is the crime of sexual harrasement through social media. From 2017 to 2020, sexual harassment through social media has increased significantly

\begin{tabular}{cc}
\hline Year & The Amount id Cases \\
\hline 2017 & 17 Cases \\
2018 & 97 Cases \\
2019 & 281 Cases \\
2020 & 786 Cases \\
\hline
\end{tabular}

Source: National Commission Against Violence Towards Women 2020.

Seeing the number of cases that are increasing every year, the need for more attention to women as victims of sexual harassment through the digital world. The problem is why cases of sexual harassment are increasing because of 1) Victim blaming; 2) legal illiteracy; 3) Lack of legal support; 4) The apparatus is less responsive. And if you look at article 27 paragraph (1) of 
the Electronics Information and Transaction Law where the article apart from the definition of decency has no clear reference, if you look at the Criminal Code, the digital is not very clear, and also the article only focuses on defending his decency, does not notice the victim and no restrictions [9].

Circumstances that do not support women make cases of sexual harassment to women continue to increase and become increasingly difficult. Because various parties justify the act of sexual harassment or make it look as if the victim is the one responsible for the crime they receive. Plus the law is also limited in scope and does not make women as legal subjects who really need to be protected from crime.

Some forms of sexual harassment that are currently problematic and have been subject to legal provisions are as follows [11]:

a. Sexting (Sex Texting), a form of verbal sexual harassment that often occurs in the digital realm. This is the activity of sending or uploading intimate content such as nude photos, semi-nude photos, as well as text messages with sexual content

b. Non-Consensual Dissemination of Intimate Images, this is the distribution of photos, sound/audio, video, or speech that contains sexual content without the person's consent. One form that is often heard is revenge porn or the spread of someone's intimate content as a form of revenge or threats.

c. Body-Shaming, in this case apart from attacking sexuality, the perpetrator of the harassment often attacks the gender aspect.

d. Scamming, is the activity of deceiving someone through dating applications or social media by creating fake stories that attract sympathy, then build the target's trust, so that the perpetrator asks for money.

If we look at the forms of sexual harassment above, it can be seen that these acts are dominated by acts that attack women non-physically but make women objects of sexual satisfaction. Acts of sexual harassment in the digital world sometimes do not get legal protection because they are considered "reasonable" by society, so that legal protection cannot be comprehensive even though it is clear that the act violates morals in society, we can see this from the table below:

\begin{tabular}{|c|c|c|}
\hline The acts of Violation & Violation of Positive Law & Violation of Morals \\
\hline $\begin{array}{l}\text { The news "Affected by Men Seducing } \\
\text { on Social Media } 14 \text { Young Women } \\
\text { Willing to Send Naked Photos and } \\
\text { Videos". }\end{array}$ & $\begin{array}{l}\text { Article } 37 \text { of Law Number } \\
44 / 2008 \text { on Pornography, } \\
\text { Article } 45 \text { paragraph } 1 \text { in } \\
\text { conjunction with } 26 \\
\text { paragraph } 1 \text { of Law }\end{array}$ & $\begin{array}{l}\text { There is a moral } \\
\text { violation }\end{array}$ \\
\hline $\begin{array}{l}\text { Source: Liputan } 6 . \text { com on August } 26^{\text {th }} \\
2020 \text {. }\end{array}$ & $\begin{array}{lr}\text { Number } 11 / 2008 \text { regarding } \\
\text { amendments to Law } \\
\text { Number } & 19 / 2016\end{array}$ & \\
\hline $\begin{array}{l}\text { In that case there was sexual harassment } \\
\text { in the form of: } \\
\text { a. Sexting (Sex Texting). } \\
\text { b. Non-Consensual Dissemination of } \\
\text { Intimate Images. } \\
\text { c. Body-Shaming. } \\
\text { d. Scamming }\end{array}$ & $\begin{array}{l}\text { concerning amendments to } \\
\text { Law } 11 / 2008 \text { concerning } \\
\text { Information and Electronic } \\
\text { Transactions }\end{array}$ & \\
\hline
\end{tabular}


The News "Perpetrators who spread
indecent photos, face 12 years in
prison".

Source: infojambi on August $28^{\text {th }} 2018$.

In such cases there is sexual harassment in the form of:

a. Sexting (Sex Testing).

b. Non-Consensual Dissemination of Intimate Images.

c. Scamming.

The victim here was invited to have sexual intercourse, which if it is done then it has fulfilled the act of which the legal subject of the victim is a child where the perpetrator makes threats of violence, commits tricks, commits a series of lies, or persuades the child to commit or allow obscene acts to be committed.

The news "GA, artists, have become suspects for not being careful in storing videos with pornographic content".

Source: Kompas.com on December $29^{\text {th }}$ 2020.

In the news, GA was charged with the Pornography Law even though she was not the perpetrator of the distribution of the video.

a. Prohibition of producing, reproducing, duplicating, disseminating, broadcasting, offering, trading, renting, providing pornography that includes grasping, sexual violence, masturbation, nude, genitalia or child pornography.

b. If men and women agree or give mutual consent to make pornographic photos or recordings, then men distribute pornography, but women previously did not give a firm statement to prohibit men from disseminating or disclosing the pornography, then women can
Article 45 paragraph 1 in conjunction with Article 27 paragraph 1 of Law Number 19/2016 concerning Amendments to Law Number 11/2008 and Article $76 \mathrm{E}$ of Law Number 23/2002 regarding amendments to Law Number 35/2014 on Childs Protection There is a moral violation

Article 4 paragraph 1 in There is a moral conjunction with Article 29 violation or Article 8 of Law Number 44/2008 on Pornography 


\begin{abstract}
be ensnared in the crime of pornography, if women previously has made a firm statement that she agrees to make pornography but does not allow men to disclose or distribute it so women have a stronger position not to be blamed for participating in the dissemination of pornography.
\end{abstract}

c. If a woman is not aware of the creation of pornographic photos or videos from the start, or does not give consent to the production of pornography, in this case the woman is called a victim.

The news "Only Knew in Social Media, Article 76D in conjunction There is a moral 16 Years Old Girl Harassed by 4 Men". with Article 81 and Article $76 \mathrm{E}$ in conjunction with Source: Okezone.com on March $11^{\text {th }}$ Article 82 of Law Number 2020. 17/2016 regarding amendments to Law Actions that violate the sense of Number 23/2002, if done to decency, or heinous acts, and are all in adults subject to Article the scope of sexual lust, such as kissing, 289-296 of the Criminal groping genitals, groping breasts, and so Code on.

The act of human trafficking for the purpose of exploiting that person in the territory of the Republic of Indonesia or outside the territory of the Republic of Indonesia.

The news: "Catcalling Verbal Abuse Can Occur in Social Media". violation

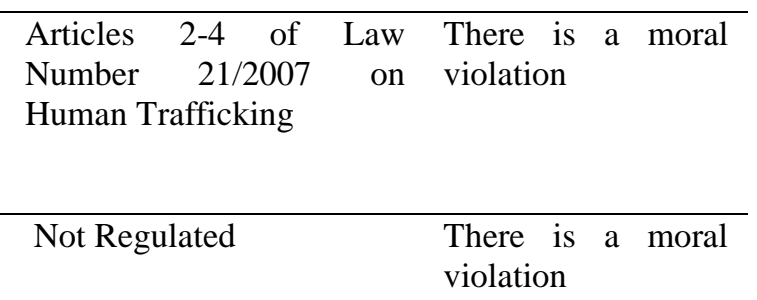

Source: rdk.fidkom,uinjkt.ac.id on July $20^{\text {th }} 2020$.

Sending messages or comments that sounds of verbal abuse on someone's upload, such as the phrase "Hi beautiful, you are sexy, you are BO, you make me lust....".

a. Request and send photos or videos that contain sexual content with the Not Regulated There is a moral consent of the victim and are not violation being disseminated.

b. Sending voice messages containing sexual content with the consent of 


the victim and not being
disseminated.

Seeing the table above explains that every violation of positive law is part of a violation of morals, but on the other hand, an act of violation is a moral violation but not a violation of positive law. It can be seen that sexual harassment in the digital world such as sending messages or comments, requesting photos or videos, and sending voice messages which are all covered with sexual content is against the law and morals. However, if the act is carried out with the consent of the victim or in the form of verbal catcalling, it is an act that violates morals but has not been regulated in Indonesian legislation. Because basically the law protects or gives a sense of security to someone from actions that violate decency or morals.

If law and morals are separated, the law will only be like an empty container that has no contents, because the law will not be able to carry out its function. This occurs because of the separation between violations of positive law and violations of morals. Regarding the separation of law and morals according to Hart, rules of recognition will not exist and work if there is a separation between legal and moral principles. Because if between law and morals are separated, for moral violations that are not regulated in violations of positive law, it is clear that there is no legal certainty and even the perpetrator cannot be ensnared by positive legal rules. In the context of a crime of decency, it has been explained that there is a limitation of language to be able to provide a high-precision definition (precision principle). The limitation of the formulation of the offense which is literally never able to provide complete and complete clarity is a situation which is recognized by experts in particular. This can be indicated by the frequent use of laws and regulations that use global generic terms and can never precisely indicate what actions are punishable by the criminal provisions [12].

According to Hart, law can be understood through two types of rules, namely primary rules and secondary rules. Hart claims the combination of these two rules is the key to understanding the law. Hart's point is that through these two types of rules many ideas about legal obligations and validity can be explained. Primary rules are the basis of people's lives. Meanwhile, the secondary rules are the rules that underlie the enforcement of the primary rules. Secondary rules consist of three types, namely rules that determine legal validity or recognition, rules that give power to certain bodies to make changes (rule of change), and rules that give someone the power to give decisions (rule of adjudication). According to Hart, the combination of primary and secondary rules is the essence of law. In other words, law for Hart is a system of rules. This view of the legal model influences Hart's view of the relationship between law and morality. Hart acknowledges that law and morality have an important relationship. However, this relationship is not an absolute relationship. That is, the definition of law does not have to involve morality; legality does not have to be determined by morality [13].

Related to the relationship between law and morality. Hart insisted that the two be separated. Hart argues that the validity of law is not determined by morality but by the rules of recognition that apply in a legal system. This means, rules that are contrary to morality and a sense of justice, as long as these rules have met official procedures or are contained in the book of Law, are considered valid rules. Thus, the law can no longer be criticized based on morality [13]. 


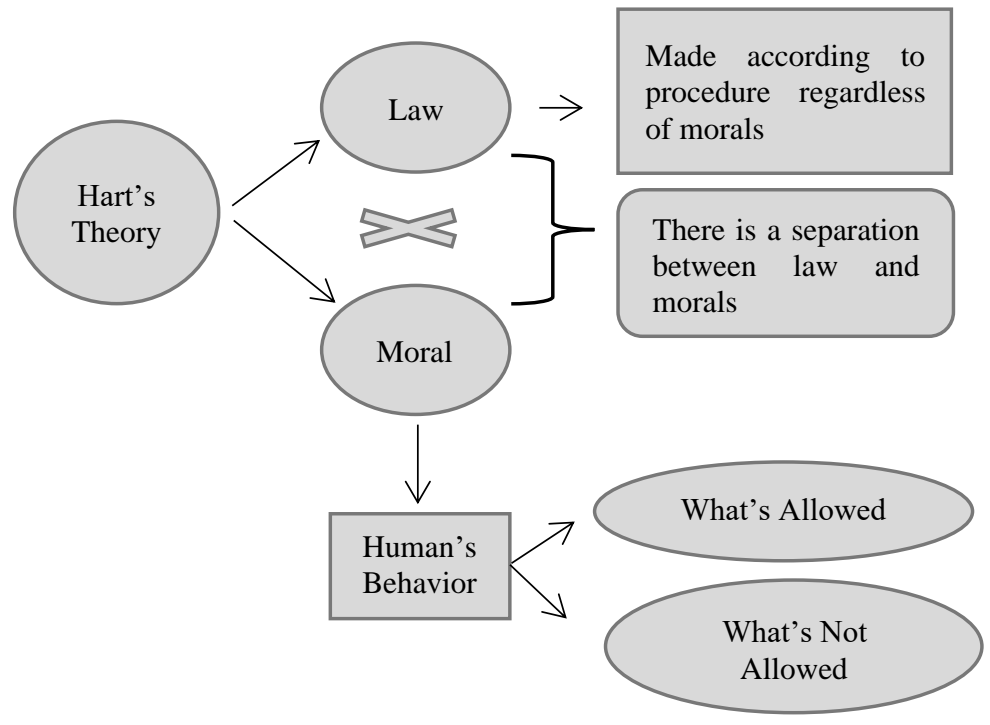

So in this case if law and morals are separated, the rule of recognition will not work, so the element of decency in question must at least refer to the provisions in court practice or the judge in making decisions must make a reference to non-legal sources (extra legal)/morals to get the most accurate and approachable interpretation and understanding. Even though a country that upholds the value of legal justice, morality takes precedence.

\subsection{How the Concept of Legal Protection for Women as Victims of Sexual Harassment in the Digital Age from the Perspective of Legal and Moral Relations?}

Law is a rule as a system of rules about human behavior [14]. The presence of law in society is among others to integrate and coordinate interests that can collide with one another, integrated by law so that collisions can be minimized [15]. The importance of legal protection is that there are rights protected by law, these rights provide enjoyment and freedom to individuals in taking action even though there are restrictions [16]. This is also emphasized in Article 28G of the 1945 Constitution where everyone has the right to legal protection and is entitled to a sense of security and protection from any threat.

From the problems above, in this case the writer takes an approach by using the concept of morality of the Medina charter law based on the prophetic paradigm. Whereas norms, along with moral and religious norms, can be seen as a "way back" to nature, or a guide to return to nature. As a public norm (to return to nature), the law must be maintained in such a way so as not to be misleading and not misled. This is a legal morality that must be upheld. In the context of this morality, the law must be a true, good, and fair in order to be materialized so that the longing to return to nature. Because if what you are looking for is the opposite, then the law will only function as a dark way that will keep people away from their nature [17].

So morals must be exist and become the core of the law, not on the contrary to separate law and morals which can make the law empty. Because the vacuum in the law makes justice unenforceable and expands the damage to the fabric of people's lives. 


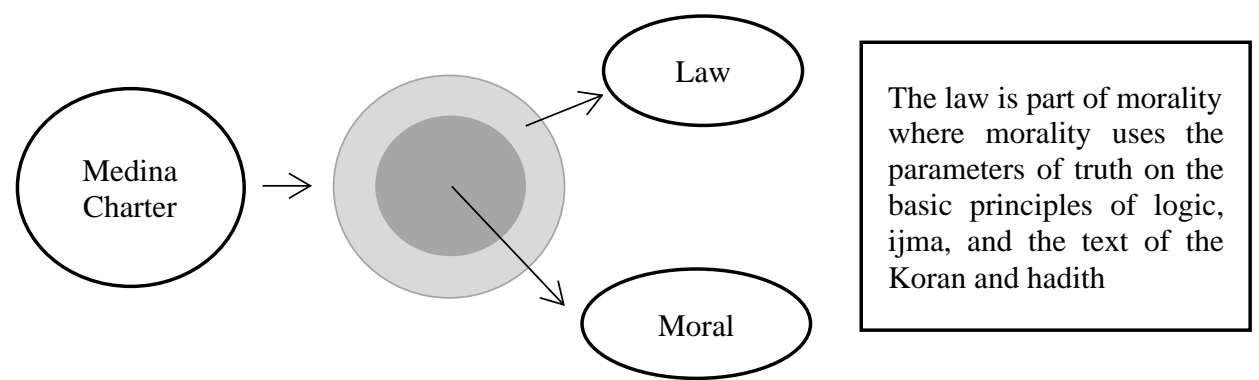

Therefore, in order to maintain the spirit of unity and integrity in the state of Medina (Ukhuwah Islamiyah), the Prophet Muhammad SAW applied the principles of a state based on the concept of "moral Islamic law" in the Medina Charter. Islamic morality is laid as the foundation for every principle/principle in the Medina Charter, where these principles are derived from the Koran and the Sunnah, including [18]:

a. The Principle of Deliberation

In dealing with every problem, deliberation is required to solve every problem of the state.

This obligation is borne by every implementation of state power in implementing its power.

b. The Principle of Justice

Upholding justice is the duty of believers, every believer when he becomes a witness he is obliged to become a witness because of Allah, honest and fair, including that humans are prohibited from following lust and distorting the truth.

c. The Principle of Equality

Whereas men and women are basically the same and have the same position.

d. The Principles of Recognition and Protection of Human Rights

That there is recognition and protection in matters of human equality, human dignity and human freedom. In this case rejects every form of treatment and attitude that might destroy the principle of equality such as discrimination in all spheres of life, feudalism, colonialism, etc.

e. Principles of Free Justice

This principle is closely related to the principles of justice and equality, that judges have free authority in the sense that every decision taken is free from anyone's influence. The principle of free trial is not only a rule of law, but also an obligation that must be carried out for every judge. Free trial is a requirement for upholding the principles of justice and equality of law.

f. The Principle of Peace

That in facing every problem, one must uphold and prioritize peace.

g. The Principle of Welfare

That the principle of welfare aims at realizing social justice and economic justice for all members of society or the people. This task is assigned to state officials and the public. In this case, it does not only provide material fulfillment but includes the spiritual needs of all the people. The state is obliged to pay attention to these two kinds of needs and provide social security for those who are underprivileged and poor.

h. The Principle of People's Obedience

In this case the relationship between the government and the people must respect and appreciate each other, mutual help, love the homeland, and create justice and prosperity. 
So that in this case, if it is related to the protection of women as victims of sexual harassment in the digital world with the concept of morality of the Medina Charter, it is necessary in this case that law is also a part of morality which becomes an inseparable unity. In terms of reform of criminal law regarding legal protection of women as victims of sexual harassment in the digital world, according to Friedman, divides it into three elements, namely the substance element, structural elements, and elements of legal culture [19].

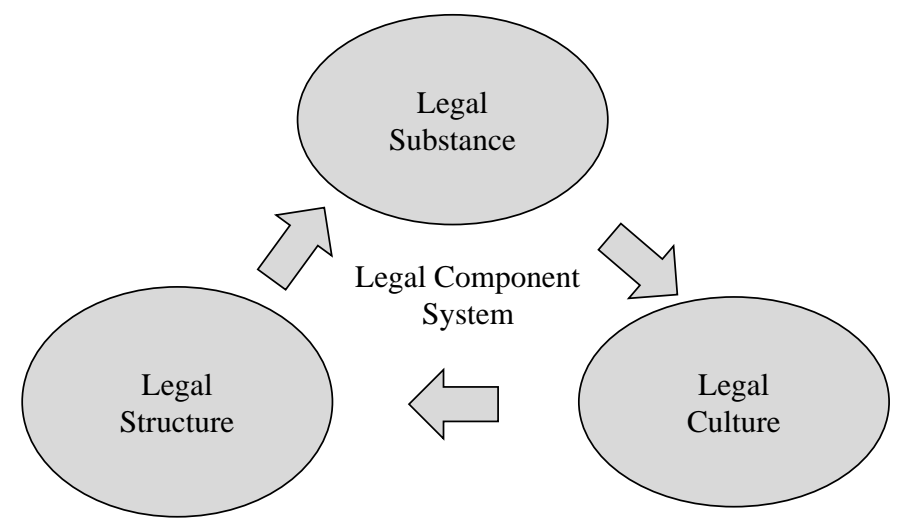

In the substance element, it is the stage of policy formulation as part of the legislative process of a statutory regulation, so that the formulation of criminal law is interpreted as an attempt to make and formulate a good criminal law [20]. In the stages or elements of substance, the merging of law and morals can be done by imitating the Medina charter which does not separate law and morals so that it can cover various aspects of interest. Protection of women needs the latest breakthrough to realize complete protection, not only relying on existing regulations, because it has been proven unable to provide protection to women. Regarding legal protection for women, namely passing/revising laws and other regulations to prevent sexual harassment that is carried out online, by prohibiting and criminalizing sexual harassment, especially the dissemination of intimate images without consent, online harassment and stalking. The criminalization of sexual harassment online must cover all elements of abuse including re-sharing of content. Then threatening to distribute intimate images/videos without consent must be made illegal so that law enforcement officials can intervene and prevent it before it occurs, and what should be highlighted is that in cases of online sexual harassment, gender perspective must be used in analyzing all forms of sexual harassment.

Then the structural element, namely the stage of the application of criminal law by law enforcement officials starting from the police, prosecutors, courts. This structural stage is the power in terms of implementing criminal law by law enforcement officials or courts [21]. So far, law enforcement officers generally do not have a gender perspective. Law enforcement officials tend to be gender biased and blaming the victim. Sensitivity to gender issues has not become a common discourse for law enforcement officials, so the victimization of victims in the legal process is still common. This is where the importance of knowledge of law enforcement officials to translate legal rules that have a gender perspective into the practice of implementation by law enforcement officials who must have gender insight and sensitivity [22].

The third element is the element of legal culture, this component of legal culture is very decisive in law enforcement efforts. There are times when law enforcement in a community is very good, because it is supported by a good culture through community participation. In a 
society like this, even though the substance and structure components are not very good the law will still run well. Likewise, if there is no support from the community, no matter how good the substance and structure is, the result will still not be good in law enforcement [23]. So that the role of legal culture by the community is very vital in its application to support the substance and structural elements in the hope that in the future someone will limit them to commit immoral acts against sexual harassment of women.

\section{Conclusion}

After discussing it, it is known that several acts of sexual harassment are moral violations but not legal violations, this is because there is a separation made by HLA Hart from morals and laws. This separation between morality and law is detrimental to women, especially because the law is unable to exist to provide complete protection to victims.

Based on the concept of the morality of the Medina Charter, the protection of women as victims of sexual harassment in the digital era needs to make law a part of morals (into an inseparable unit). If the law is separate from morals, then moral violations that are not regulated in violations of positive law are clear there is no legal certainty and even the perpetrator cannot be ensnared by positive legal rules.

So it is necessary to enact/revise laws and other regulations to prevent sexual harassment that is carried out online, by prohibiting and criminalizing sexual harassment, especially the dissemination of intimate images without consent, online harassment and stalking. The criminalization of sexual harassment online must cover all elements of abuse including resharing of content. Then threatening to distribute intimate images/videos without consent must be made illegal so that law enforcement officials can intervene and prevent it before it occurs, and what should be highlighted is that in cases of online sexual harassment, gender perspective must be used in analyzing all forms of sexual harassment.

\section{References}

[1] E. Setiadi, "Perlindungan Hukum Bagi Wanita dari Tindakan Kekerasan," Mimb. J. Sos. dan Pembang., vol. 17, no. 3, pp. 338-354, 2001.

[2] H. E. I. Santoso, "Perlindungan Hukum Bagi Anak Korban Tindak Pidana Pelecehan Seksual," Lex J. Kaji. Huk. Keadilan, vol. 3, no. 2, 2020.

[3] M. Sumera, "Perbuatan Kekerasan/Pelecehan Seksual Terhadap Perempuan," Lex Soc., vol. 1, no. 2, 2013.

[4] L. I. Nurtjahyo, "Kekerasan Seksual di Internet Meningkat Selama Pandemi dan Sasar Anak Muda: Kenali Bentuknya dan Apa yang Bisa Dilakukan?," The Conversation, 2020. [Online]. Available: https://theconversation.com/kekerasan-seksual-di-internet-meningkat-selamapandemi-dan-sasar-anak-muda-kenali-bentuknya-dan-apa-yang-bisa-dilakukan-152230.

[5] Southeast Asia Freeedom of Expression Network, "Pelecehan Seksual Pada Pekerja Saat WFH," Southeast Asia Freeedom of Expression Network, 2020. [Online]. Available: https://id.safenet.or.id/2020/06/wfh-rentan-pelecehan-seksual-perusahaan-didesak-buatprotokol-anti-pelecehan-seksual.

[6] Mahkamah Konstitusi Republik Indonesia, Putusan Mahkamah Konstitusi Republik Indonesia Nomor 46/PUU-XIV/2016. 2016, p. 455.

[7] D. Rahmat, "Penyuluhan Hukum di Desa Sampora Tentang Perlindungan Hukum Korban Pelecehan Seksual Terhadap Perempuan di Indonesia," Empower. J. Pengabdi. Masy., vol. 3, no. 
01, 2020.

[8] J. Ramad, "5 Kasus Pelecehan Seksual yang Viral Dua Pekan Terakhir, Tiga Pelaku Tertangkap,"
Kompas.com,
2020
[Online].
Available: https://megapolitan.kompas.com/read/2020/01/26/10580911/5-kasus-pelecehan-seksual-yangviral-dua-pekan-terakhir-tiga-pelaku?page=all.

[9] T. Pawesti, "Online Harassment, Sexism, and Gender Based Violence." Webinar Peluncuran Riset ICJR: Mengatur Ulang Kebijakan Pidana di Ruang Siber, 2021.

[10] A. Ricardo, "Karakteristik Pelaku Pelanggaran Seksual," J. Kedokt. Meditek, 2016.

[11] S. K. Haryadi, "Waspada! Ini Jenis-jenis Pelecehan Seksual di Ranah Digital yang Harus Kamu Tahu," SINDOnews.com, $2020 . \quad$ [Online]. Available: https://gensindo.sindonews.com/read/128474/700/waspada-ini-jenis-jenis-pelecehan-seksual-diranah-digital-yang-harus-kamu-tahu-1597039723.

[12] E. A. T. Napitupulu and S. W. Eddyono, "Korban Pelecehan yang Menjadi Tersangka Pasal 27 Ayat (1) UU ITE; Amicus Curiae (Sahabat Pengadilan) dalam Kasus Baiq Nuril Maknun Pada Nomor Register Perkara: 265/Pid.Sus/2017/PN. Mtr di Pengadilan Negeri Mataram.” Institute for Criminal Justice Reform (ICJR), pp. 1-25, 2017.

[13] P. C. K. L. Bello, "Hubungan Hukum dan Moralitas Menurut HLA Hart," J. Huk. Pembang., vol. 43, no. 3, pp. 348-361, 2017.

[14] J. Asshiddiqie and M. A. Safa, Teori Hans Kelsen Tentang Hukum. Jakarta: Konstitusi Press, 2012.

[15] R. Satjipto, "Ilmu Hukum." Cetakan ke-IV, PT. Citra Aditya Bakti, Bandung, 2006.

[16] S. Mertokusumo, "Mengenal Hukum (Suatu Pengantar)," Lib. Yogyakarta. hlm, vol. 41, 2008.

[17] F. Hamdani, "Paradigma Profetik: Antara Konsep Moralitas Piagam Madinah dan Konsep Moralitas Hukum H.L.A Hart," Jurisprudence, vol. 6, no. 1, 2016.

[18] K. Wardiono and K. Dimyati, "Basis Epistemologis Paradigma Rasional Dalam Ilmu Hukum: Sebuah Deskripsi Tentang Asumsi-Asumsi Dasar Teori Hukum Murni-Hans Kelsen,” J. Din. Huk., vol. 14, no. 3, pp. 369-383, 2014.

[19] L. M. Friedman, "Sistem Hukum Perspektif Ilmu Sosial," Bandung Nusa Media, 2009.

[20] B. N. Arief, Kebijakan legislatif dalam penanggulangan kejahatan dengan pidana penjara. Badan Penerbit, Universitas Diponegoro, 1996.

[21] S. Bakhri and T. P. Narkotik, "Psikotropika, Suatu Pendekatan Melalui Kebijakan Hukum Pidana," Bekasi Gram. Publ., 2012.

[22] V. Ariyanti, "Pembaharuan Hukum Pidana di Indonesia yang Berkeadilan Gender dalam Ranah Kebijakan Formulasi, Aplikasi, dan Eksekusi," Halu Oleo Law Rev., vol. 3, no. 2, pp. 178-195, 2019.

[23] A. Fendri, "Perbaikan sistem hukum dalam pembangunan hukum di indonesia," J. Ilmu Huk., vol. 1, no. $2,2011$. 